УДК 616.33-002.44-089-06

DOI 10.11603/2414-4533.2017.3.7938

(С). В. ГРИНЧУК, А. Ф. ГРИНЧУК

ВДНз України “Буковинський державний медичний університет”

\title{
Способи виходу із деяких складних ситуацій у хірургії гострих ускладнень виразкової хвороби
}

\begin{abstract}
Мета роботи: ознайомлення широкого кола хірургів з напрацьованими методами гастропластики і формування дуоденостоми. Матеріали і методи. У дослідження включено 16 чоловіків віком від 47 до 72 років. Перфорація гігантської виразки шлунка була у 11 випадках, кровотеча з виразки - в решти. Дифузний перитоніт виявлено у 8 (72,72 \%) випадках, розлитий - у 3 (27,28 \%). У хворих з кровотечею ендоскопічне і консервативне лікування були неефективними. У 15 хворих виконали висічення виразки, після чого діаметр дефекту становив 8-14 см. В одного хворого на синдром Золінгера-Елісона з приводу перфорації виразки шлунка виконано субтотальну резекцію шлунка. Гастропластику після висічення виразки проводили за напрацьованою методикою, яка полягає у застосуванні косого напрямку зашивання дефекту.

Результати досліджень та їх обговорення. Застосування такого способу гастропластики приводить до відновлення звичайної форми шлунка. Через 1-2 роки після операції обстежено 9 хворих. У жодного з них не було проявів каскадної деформації шлунка. У хворого на синдром Золінгера-Елісона у зв’язку з повторними перфораціями виразок кукси ДПК використали розроблений метод дуоденостомії, за якого навколо кукси і трубки фіксується пересічена кругла зв’язка печінки. Розвитку неспроможності дуоденостоми не було. Отже, напрацьовані методи можуть бути використані у відповідних складних інтраопераційних ситуаціях.
\end{abstract}

Ключові слова: виразкова хвороба; синдром Золінгера-Елісона; гастропластика; дуоденостомія.

Постановка проблеми і аналіз останніх досліджень та публікацій. Завдяки впровадженню сучасних схем лікування зменшилась кількість хірургічних втручань з приводу виразкової хвороби та її ускладнень [1, 2]. Рідше зустрічаються інтраопераційні проблеми, зумовлені великими виразковими інфільтратами, гігантськими виразками тощо. Це сприяє використанню малоінвазивних втручань, спрощує хірургічну техніку [3, 4]. Втім повністю уникнути складних ситуацій, зумовлених агресивним перебігом виразкової хвороби неможливо, тому актуальним залишається напрацювання способів виходу з таких ситуацій.

Мета роботи: ознайомлення широкого кола хірургів з напрацьованими методами пластики шлунка і формування дуоденостоми.

Матеріали і методи. У дослідження включено 16 чоловіків віком від 47 до 72 років. Перфо-

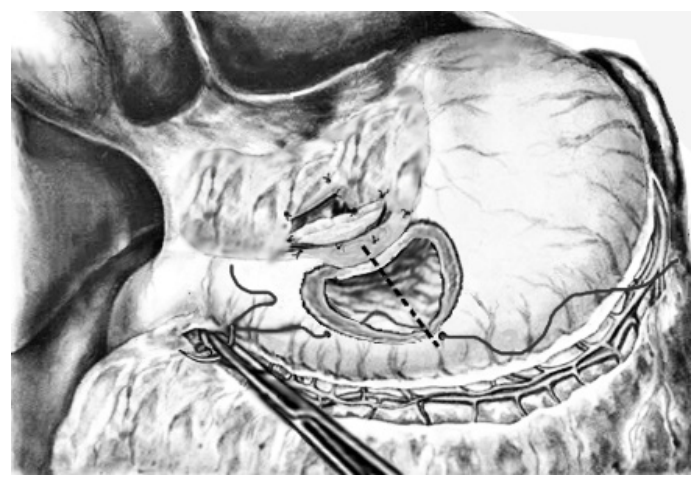

A рація гігантської виразки шлунка була у 11 випадках, кровотеча з виразки - у решти. Всі хворі на перфорацію надійшли в період 18-36 год від початку захворювання. Дифузний перитоніт виявлено у 8 (72,72 \%) випадках, розлитий - у 3 (27,28 \%). У хворих на кровотечу ендоскопічний гемостаз і консервативне лікування були неефективними.

У 15 хворих виконали висічення виразки, після чого діаметр залишкового дефекту становив 8-14 см. У одного хворого на синдром ЗолінгераЕлісона з перфорацією виразки шлунка виконана вимушена субтотальна резекція шлунка.

Гастропластику після висічення виразки проводили за напрацьованою методикою (рис. 1), яка передбачає косий напрям накладання швів на дефект. Перший вкол голки робили у лівому куті рани шлунка. Викол голки на протилежній стінці дефекту проводили несиметрично до поперечної осі рани, а зі зміщенням вправо. Місце виколу зміщу-

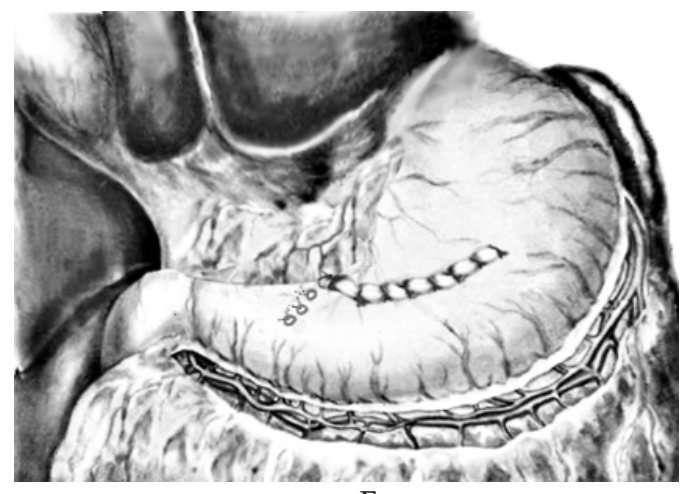

Б

Рис. 1. Схема виконання напрацьованого способу гастропластики. 
вали правіше на 2 - 4 см (залежно від розмірів дефекту шлунка) відносно точки вколу (рис. 1, А), так, щоб шов проходив косо відносно поперечної осі рани шлунка на 45-350, що залежало від індивідуальних потреб. Подальше зашивання проводили із збереженням зазначених співвідношень.

Результати досліджень та їх обговорення. В результаті застосування запропонованої техніки пластики відбувалось зміщення стінок шлунка. Лінія швів набувала еліпсоїдної конфігурації (рис. 1, Б) і майже відновлювалась звичайна форма шлунка. Санацію очеревинної порожнини проводили розчином декасану. Після операції хворим призначали комплексне консервативне лікування, яке включало розчин Рингера, трисоль, сорбілакт, ГІК, цефтріаксон у комбінації з грандазолом, флуконазол, противиразкову терапію. Всі пацієнти одужали.

У віддалений післяопераційний період (1-2 роки) обстежено 9 хворих, у 2 (22,22 \%) були скарги, характерні хворобам оперованого шлунка. Рентгенологічне і ендоскопічне обстеження ознак каскадної деформації не виявило. Патологічні прояви (тяжкість у епігастрії, нудота, болі) зумовлювались в одного пацієнта виразним гастродуоденітом, у іншого - субкомпенсованим стенозом воротаря.

У хворого на синдром Золінгера-Елісона через 9 діб після виконання резекції шлунка виникли повторні перфорації виразок кукси ДПК. Були застосовані запрограмовані повторні втручання. Зашивання виразок було неефективне, тому була сформована дуоденостома за напрацьованою методикою (рис. 2). Через дефект у просвіт кукси заведена трубка, фіксована циркулярним швом до стінки ДПК, пересічена і низведена кругла зв'язка печінки (рис. 2, А). У круглій зв’язці зроблений тунель, через який проведена трубка (рис. 2, Б). Розріз по задньому краю зв'язки розширений i краї дефекту підшиті окремими швами до стінки ДПК навколо трубки, остання виведена назовні через прокол черевної стінки, передній край зв’язки фіксований до парієтальної очеревини навколо трубки (рис. 2, В). Таким чином, дефект ДПК був ізольований від очеревинної порожнини. В подальшому у хворого повторювались перфорації гострих виразок кукси шлунка, прогресував перитоніт, що призвело до смерті, проте на секції ознак неспроможності дуоденостоми не виявлено.
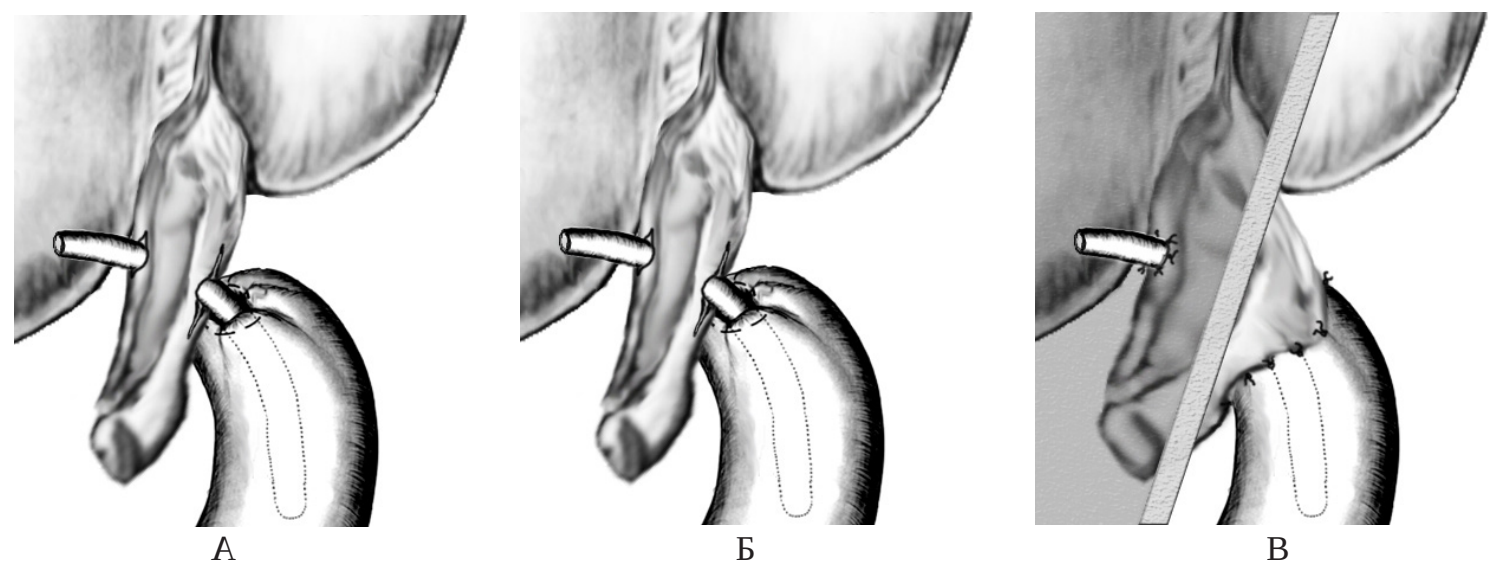

Рис. 2. Схема виконання напрацьованого способу дуоденостомії.

Отже, викладене свідчить, що напрацьовані методи гастропластики і дуоденостомії $є$ ефективними. Зазначимо, що вони є простими у виконанні, не потребують спеціальних засобів чи окремої підготовки хірурга і можуть бути використані у стаціонарах різного рівня. На нашу думку, запропоновану техніку дуоденостомії можна використовувати у разі неспроможності кукси ДПК чи необхідності формування інших видів стом.

\section{СПИСОК ЛІТЕРАТУРИ}

1. Дзюбановський І. Я. Аналіз результатів обстеження пацієнтів із виразковою хворобою шлунка на основі кореляційних показників та багатопараметричної нейромережевої
Висновки. 1. Напрацьований метод пластики великих дефектів шлунка дозволяє уникнути розвитку його деформації у віддалений післяопераційний період, що покращує якість життя хворих.

2. Застосована методика дуоденостомії з використанням круглої зв'язки печінки може бути використана як метод виходу із складної ситуації у разі наявності дефектів кукси дванадцятипалої кишки, що не піддаються закриванню стандартними способами.

кластеризації з метою оптимізації прогнозування перебігу захворювання / І. Я. Дзюбановський, П. Р. Сельський, Л. Є. Війтович // Вісн. наук. досліджень. - 2014. - № 1. - С. 44-46. 
2. Outcomes of a randomized controlled trial comparing modified high dose Omeprazole and Amoxicillin triple therapy with standard triple therapy for Helicobacter Pylori eradication / K. Chunlertlith, U. Limpapanasit, P. Mairiang [et al.] // Asian. Pac. J. Cancer Prev. - 2017. - Vol. 18, № 4. - P. 927-932. doi:10.22034/APJCP.2017.18.4.927

3. Тутченко М. I. Порівняльна оцінка ефективності радикальних відкритих та лапароскопічних операцій у лікуванні

\section{REFERENCES.}

1. Dziubanovskyi, I.Ia., Selskyi, P.R., \& Viitovych, L.Ie. (2014). Analiz rezultativ obstezhennia patsiientiv iz vyrazkovoiu khvoroboiu shlunka na osnovi koreliatsiinykh pokaznykiv ta bahatoparametrychnoi neiromerezhevoi klasteryzatsii z metoiu optymizatsii prohnozuvannia perebihu zakhvoriuvannia [Analysis of the survey results of patients with ulcer disease based on correlation indices and multiparameter neuronetwork clasterization to optimize the prognosis of the disease]. Visnyk naukovykh doslidzhen - Journal of Scientific Research, 1, 44-46 [in Ukrainian].

2. Chunlertlith K., Limpapanasit U., Mairiang P., Vannaprasaht S., Tassaneeyakul W., Sangchan A., ... Pattarapongsin M. (2017). Outcomes of a randomized controlled trial comparing modified high dose Omeprazole and Amoxicillin triple therapy with standard triple therapy for Helicobacter Pylori eradication. перфоративної виразки дванадцятипалої кишки / М. І. Тутченко, Д. В. Ярощук // Хірургія України. - 2013. - № 4. C. $12-20$.

4. Laparoscopic and open surgical treatment in gastroduodenal perforations: our experience / R. Laforgia, G. Balducci, G. Carbotta [et al.] // Surg. Laparosc. Endosc. Percutan. Tech. - 2017. - Vol. 27, № 2. - P. 113-115. doi: 10.1097/SLE.0000000000000376

Asian Pacific Journal of Cancer Prevention, 18 (4), 927-932. doi:10.22034/APJCP.2017.18.4.927

3. Tutchenko, M.I., \& Yaroshchuk, D.V. (2013). Porivnialna otsinka efektyvnosti radykalnykh vidkrytykh ta laparoskopichnykh operatsii u likuvanni perforatyvnoi vyrazky dvanadtsiatypaloi kyshky [Comparative effectiveness of the radical open and laparoscopic surgery for perforated duodenal ulcer]. Khirurhiia Ukrainy - Surgery of Ukraine, 4, 12-20 [in Ukrainian].

4. Laforgia, R., Balducci, G., Carbotta, G., Prestera, A., Sederino, M.G., Casamassima, G., ... Palasciano, N. (2017). Laparoscopic and open surgical treatment in gastroduodenal perforations: our experience. Surgical Laparoscopy Endoscopy \& Percutaneous Techniques, 27 (2), 113-115. doi: 10.1097/ SLE.0000000000000376

\section{SOLUTIONS TO SOME COMPLICATED SITUATIONS IN THE SURGERY OF ACUTE COMPLICATIONS OF PEPTIC ULSER}

The aim of the work: to introduce to a wide range of surgeons the best methods developed so far of a gastroplasty and duodenostomy formation.

Materials and Methods. 16 men aged 47 to 72 years old. Perforation of the giant stomach ulcer occurred in 11 cases, bleeding from ulcers - in the rest. The diffuse peritonitis is identified in 8 (72.72 \%) cases, total - in 3 (27.28 \%). Endoscopic and conservative treatment were ineffective for patients with bleeding. An excision of the ulcer was done to 15 patients, and the diameter of the defect was 8-14 cm afterwards. Due to the perforation of the gastric ulcer to the patient with the Zollinger-Ellison syndrome, the subtotal gastrectomy was carried out. The gastroplasty after the ulcer incision was carried out using the elaborated procedure, which is applied through slanting direction suturing of a defect.

Results and Discussion. The use of such gastroplasty method leads to a restoration of the usual form of the stomach. In 1-2 years after the operation, 9 patients were examined. None of them had any display of cascade deformation of the stomach. The patient with the Zollinger-Ellison syndrome, due to the second time perforations of the duodenum stump ulcers, the duodenostomy developed method was used, when a cut round ligament of the liver is fixed around the stump and a tube. No insolvency of duodenostomy was found. So, the elaborated methods can be used in corresponding complicated intraoperational situations.

Key words: peptic ulcer; Zollinger-Ellison syndrome; gastroplasty; duodenostomy. 
Ф. В. ГРИНЧУК, А. Ф. ГРИНЧУК

ВГУз Украины “Буковинский государственный медицинский университет”

\section{СПОСОБЫ ВЫХОДА ИЗ НЕКОТОРЫХ С.ОЖНЫХ СИТУАЦИЙ В ХИРУРГИИ ОСТРЫХ ОС.ЛЖНЕНИЙ ЯЗВЕННОЙ БО.ЕЗНИ}

Цель работы: ознакомление широкого круга хирургов с разработанными методами пластики желудка и формирования дуоденостомы.

Материалы и методы. В исследования включены 16 мужчин в возрасте от 47 до 72 лет. Перфорация гигантской язвы желудка была в 11 случаях, кровотечение из язвы - в остальных. Диффузный перитонит выявлен в 8 (72,72 \%) случаях, разлитой - в 3 (27,28 \%). У больных с кровотечением эндоскопическое и консервативное лечение были неэффективными. У 15 больных выполнили иссечение язвы, после чего диаметр дефекта составил 8-14 см. У одного больного с синдромом ЗоллингераЭллисона по поводу перфорации язвы желудка выполнена субтотальная резекция желудка. Гастропластику после иссечения язвы проводили по наработанной методике, которая заключается в применении косого направления зашивания дефекта.

Результаты исследований и их обсуждение. Применение такого способа гастропластики приводит к восстановлению обычной формы желудка. Через 1-2 года после операции обследовано 9 больных. Ни у одного из них не было проявлений каскадной деформации желудка. У больного с синдромом Золлингера-Эллисона в связи с повторными перфорациями язв культи ДПК использовали разработанный метод дуоденостомии, при котором вокруг культи и трубки фиксируется пересеченная круглая связка печени. Развития несостоятельности дуоденостомы не было. Итак, наработанные методы могут быть использованы в соответствующих сложных интраоперационных ситуациях.

Ключевые слова: язвенная болезнь; синдром Золлингера-Эллисона; гастропластика; дуоденостомия. 